\title{
MEKANISME KERJA COSTUMER SERVICE DALAM AKTIVITAS OPERASIONAL PT. BANK SYARI'AH MANDIRI (BSM) Tbk CAB. PADANG
}

\author{
Rosi Puspita Sari, Afriyeni \\ Akademi Keuangan dan Perbankan Padang \\ Afriyeni.yen@gmail.com
}

\begin{abstract}
ABSTRAK
Tujuan dari penelitian ini adalah bagaimana Mekanisme Kerja Customer Service Dalam Aktivitas Operasional PT. Bank Syari'ah Mandiri Tbk Cabang Padang. Untuk menganalisa data penelitian, penulis menggunakan analisa deskriptif. Metode analisa deskriptif yang dipakai adalah terhadap mekanisme kerja Customer Service di PT. Bank Syari'ah Mandiri Tbk Cabang Padang. Mekanisme kerja CS pada saat pagi hari yaitu menyiapkan counter CS bersih, rapih dan senyaman mungkin. Kemudian pada saat jam kerja CS benar-benar harus fokus terhadap pelayanan kepada nasabah, mulai dari pembukaan dan penutupan rekening Giro, pembukaan dan penutupan rekening Tabungan, pembukaan dan pencairan Deposito, serta melayani semua kebutuhan dan keluhan nasabah. Pada jam istirahat petugas CS harus bergantian, karena counter CS tidak boleh kosong. Kemudian waktu sore hari dan tutup harian, CS harus telah menyelesaikan semua tugas pada hari itu, dan membuat dead-line untuk tugas yang dipending dan akan dikerjakan esok harinya.
\end{abstract}

Kata Kunci: Customer Service, Operasional

\section{LATAR BELAKANG}

Menurut Undang-undang Nomor 7 tahun 1992 tentang Perbankan sebagaimana telah diubah dengan Undang-undang Nomor 10 tahun 1998 pengertian bank adalah badan usaha yang menghimpun dana dari masyarakat dalam bentuk simpanan dan menyalurkannya kepada masyarakat dalam bentuk kredit dan atau bentuk-bentuk lainnya dalam rangka meningkatkan taraf hidup rakyat banyak.

Pengertian di atas memiliki kandungan filosofis yang tinggi. Pengertian yang lebih teknis dapat ditemukan pada Standar Akuntansi Keuangan (PSAK) dan Surat Keputusan Menteri Keuangan RI Nomor 792 Tahun 1990. Pengertian bank menurut PSAK Nomor 31 dalam Standar Akuntansi Keuangan (1999: 31.1) sebagai berikut: Bank adalah suatu lembaga yang berperan sebagai perantara keuangan antara pihak-pihak yang memiliki kelebihan dana dan pihak-pihak yang memerlukan dana, serta sebagai lembaga yang berfungsi memperlancar lalu lintas pembayaran

Sedangkan berdasarkan SK Menteri Keuangan RI Nomor 792 tahun 1990 pengertian bank adalah: "suatu badan yang kegiatannya di bidang keuangan melakukan penghimpunan dan penyaluran dana kepada masyarakat". 
Secara umum pengertian Customer Service adalah setiap kegiatan yang bertujuan memberikan kepuasan nasabah, melalui pelayanan yang bermutu yang dapat memenuhi keinginan dan kebutuhan nasabah. Dengan adanya pelayanan yang baik tersebut membuat nasabah merasa senang dan dihargai, sehingga nasabah akan kembali lagi dan melanjutkan hubungan bisnis dengan bank tersebut, kemudian akan menceritakan kepuasan dan kebaikan pelayanan yang diperolehnya kepada orang lain.

Pada prinsipnya semua atau seluruh pegawai bank mulai dari Cleaning Service, Satpam, sampai kepada Direktur Utama bank harus menjadi Customer Service. Namun secara khusus tugas CS ini diemban oleh orang yang memang dididik untuk memegang fungsi sebagai CS disuatu bank.

Bank adalah perusahaan jasa, dengan kata lain bahwa bank adalah perusahaan yang menjual jasa kepada masyarakat. Untuk itu, bank akan memberikan pelayanan yang terbaik untuk nasabah, karena bagi bank nasabah itu adalah raja. Banyaknya bank yang ada di Indonesia khususnya di kota Padang menimbulkan persaingan yang sangat ketat dan berlomba untuk memperoleh tingkat yang paling baik di mata masyarakat, oleh sebab itu diperlukan strategi yang baik dan tepat oleh masing-masing lembaga guna meningkatkan laba perusahaan dan memiliki kualitas yang bermutu. Salah satu cara yang tepat adalah adanya peranan CS dalam meningkatkan pelayanan terhadap nasabah, karena pelayanan yang bermutu merupakan kunci sukses dan dasar untuk membangun keberhasilan di perusahaan perbankan. Dalam hal ini, tidak semua karyawan bank itu berhubungan langsung dengan nasabah, karena sesuai dengan tugas dan fungsinya masing-masing. Karyawan bank yang paling sering dan memang tugasnya selalu berhubungan langsung dengan nasabah salah satunya adalah CS.

Dengan semakin tingginya persaingan didunia perbankan dan semakin sulitnya memuaskan keinginan nasabah, maka kita tahu bahwa pekerjaan seorang CS tidak lah ringan, karena tugasnya menjembatani komunikasi antara nasabah dan perusahaan sehubungan dengan produk dan jasa yang dijual oleh perusahaan yang akan dibutuhkan oleh nasabah yang bertujuan untuk terjalinnya hubungan kerjasama dalam waktu yang lama dengan nasabah.

Customer Service adalah salah satu ujung tombak terpenting bagi perusahaan dalam membangun kepuasan nasabah, melalui CS perusahaan dapat memberikan persepsi yang positif kepada nasabah, dan perusahaan dapat mengetahui tentang keluhan, kebutuhan, dan keinginan nasabah. Untuk itu CS harus mempunyai keahlian, pengetahuan, dan penampilan yang bisa membuat nasabah merasa tidak dikecewakan. Karena jika nasabah merasa puas dengan pelayanan yang diberikan oleh CS, maka nasabah akan memandang bahwa bank tersebut adalah yang terbaik, dan biasanya akan menjadi nasabah tetap di bank tersebut dan itu merupakan keuntungan bagi bank. Begitupun sebaliknya seandainya nasabah merasa kecewa dengan pelayanan yang diberikan oleh CS maka nasabah akan berfikir bahwa bank tersebut tidak layak dipilih, dan ini merupakan kerugian bagi bank.

Berdasarkan pengamatan penulis yang pernah magang selama dua bulan di PT.Bank Syariah Mandiri Cabang Padang, penulis sangat tertarik dengan pelayanan yang diberikan oleh CS. Sebagai frontliner CS benar-benar dituntut 
untuk memberikan yang terbaik kepada nasabah, hal ini ditunjukkan oleh pihak Manajemen dengan cara melakukan Role-Play setiap hari kerja selama lima belas menit, sebelum jam kerja dimulai.

Dari uraian diatas, dan untuk memberikan gambaran yang jelas tentang apa dan bagaimana cara kerja Customer Service dalam melaksanakan pelayanan terhadap nasabah dan untuk menambah pemahaman masyarakat terhadap apa dan bagaimana sikap serta kinerja CS dalam aktivitas operasional bank, maka penulis tertarik untuk membahas dan menuangkannya dalam bentuk tugas akhir yang diberi judul "Mekanisme Kerja Customer Service Dalam Aktivitas Operasional PT.Bank Syari'ah Mandiri Tbk Cab. Padang"

\section{METODE PENELITIAN}

Adapun metode penelitian yang digunakan dalam penyusunan tugas akhir ini adalah metode Penelitian Deskriptif dengan langkah-langkah sebagai berikut :

\section{Teknik Pengumpulan Data}

Teknik pengumpulan data yang dilakukan penulis adalah penelitian perpustakaan dan penelitian lapangan.

1) Penelitian Perpustakaan

Penelitian ini dilakukan dengan mengumpulkan data dengan menggunakan teori-teori yang berkaitan dengan masalah-masalah yang akan dibahas, yang diperoleh dari literatur yang ada berupa buku-buku yang berkaitan dengan masalah yang akan diteliti.

2) Penelitian lapangan

Pada penelitian ini dilakukan dengan cara melakukan pengamatan langsung dan melakukan wawancara dengan pihak - pihak yang terkait, yang dapat penulis ambil keterangan dan penjelasan.

\section{Teknik Analisa Deskriptif}

Untuk menganalisa data penelitian, penulis menggunakan analisa deskriptif. Metode analisa deskriptif yang dipakai adalah terhadap mekanisme kerja Customer Service di PT.Bank Syari'ah Mandiri Tbk Cab. Padang.

\section{LANDASAN TEORI}

Bank selaku lembaga keuangan yang tugasnnya adalah memberikan jasajasa keuangan melalui penitipan uang (simpanan) dalam bentuk Giro, Tabungan dan Deposito. Kemudian menyalurkannya melalui pemberian kredit (pembiayaan), serta jasa-jasa keuangan lainnya, untuk itu bank harus menjaga kepercayaan yang diberikan oleh nasabah. Kepercayaan sangat penting dan tinggi nilainya, karena tanpa kepercayaan masyarakat (nasabah) mustahil bank itu dapat tumbuh dan berkembang.

Untuk menjaga dan meningkatkan kepercayaan nasabah, maka bank perlu menjaga citra positif dimata nasabah. Citra ini dapat di bangun melalui kualitas produk, kualitas pelayanan, kualitas kedisiplinan dan kualitas amanah (kepercayaan). Dalam memperhatikan kualitas produk petugas CS harus menjaga area kerja CS secara keseluruhan, mulai dari peralatan kerja CS harus lengkap, 
dapat digunakan dan berfungsi dengan baik, meja yang bersih dan rapi, formulir dan kartu yang akan dibutuhkan oleh nasabah, stempel perusahaan, pesawat telepon, komputer dan semua peralatan CS lainnya.

Sedangkan dalam memperhatikan kualitas pelayanan mulai dari memberikan "salam" dan "senyum" kepada nasabah yang langsung datang ataupun komunikasi lewat telepon, membantu dan menjawab pertanyaan nasabah dengan benar serta menanangani keluhan nasabah dengan baik dan sopan mencatat serta mendokumentasikan data-data yang berhubungan dengan transaksi nasabah.

Dalam hal menjaga kepercayaan (amanah) nasabah, seorang petugas CS harus benar-benar peduli dengan pengarsipan data-data nasabah, baik data yang baru ataupun data-data yang telah dilakukan perubahan. Sebagian besar nasabah BSM adalah nasabah yang loyalis. Meskipin mereka belum puas terhadap layanan yang diberikan BSM namun mereka mempunyai harapan-harapan untuk BSM ke depan.

BSM penting memperhatikan harapan-harapan nasabah tersebut agar loyalitas nasabah tidak berkurang dan ketidakpuasan dapat berkurang. Harapan utama dan kuat nasabah terhadap dimensi pelayanan BSM adalah peningkatan sosialisasi, edukasi, dan promosi BSM kepada masyarakat yang sudah jadi nasabah maupun belum, pemenuhan komitmen sesuai syari'ah, dan peningkatan profesionalitas.

Harapan lain yang cukup kuat adalah nasabah meminta peningkatan pelayanan (ramah, cepat, dan akurat) dan peningkatan kenyamanan kantor. Beberapa cara untuk meningkatan kepuasan nasabah dan mempertahankan loyalitas nasabah,yakni sebagai berikut :

1) Unit-unit kerja yang terkait dalam pembinaan pelayanan dapat lebih kuat lagi dalam membina hal-hal yang berkaitan dengan pelayanan masingmasing kanwil dan cabang-cabang dibawahnya sesuai dengan bidang kerja masing-masing unit kerja.

2) Unit-unit kerja yang terkait dengan sosialisasi, edukasi, dan promosi BSM, dapat meningkatkan kegiatan sosialisasi, edukasi, dan promosi kepada masyarakat yang sudah menjadi nasabah maupun belum jadi nasabah.

3) Unit-unit kerja yang berkaitan dengan jaringan dan pelayanan ATM dapat membuat program-program yang membuat nasabah yakin bahwa BSM mempunyai jaringan ATM yang luas dan fungsional di seluruh wilayah Indonesia.

Seorang nasabah yang puas bagi sebuah bank adalah jika nasabah merasa mendapatkan value dari bank sebagai penyedia produk dan layanan transaksi perbankan. Value ini bisa berasal dari produk, pelayanan, sistem, atau sesuatu yang bersifat emosi.jika nasabah menyatakan value adalah produk yang berkualitas maka kepuasan terjadi bila nasabah mendapatkan produk berkualitas.

Apabila value bagi nasabah adalah kenyamanan maka kepuasan terjadi jika nasabah mendapatkan pelayanan yang nyaman. Demikian seterusnya.

Kualitas layanan yang berasal dari produk, pelayanan,ataupun sistem sangat gampang ditiru. Sehingga nasabah akan bertahan jika faktor emosional ikut mempengaruhi keputusan nasabah. Nasabah akan terus memanfaatkan 
produk/jasa yang telah mempengaruhi emosionalnya jika memperoleh kemudahan untuk memperoleh produk atau jasa tersebut.

Nasabah yang puas dapat meningkat menjadi nasabah yang loyal.

Istilah-istilah yang berkaitan dengan mekanisme kerja Customer Service dalam Aktivitas Operasional PT.Bank Syari'ah Mandiri cabang Padang.

Mekanisme : Cara kerja suatu organisasi (perusahaan) dan sebagainya.

Kerja $\quad$ : Sesuatu yang kita lakukan dengan untuk mencapai hasil/tujuan yang diinginkan

Customer Service : Suatu jabatan pekerjaan pada salah satu kegiatan operasional bank yang bertugas melayani dan menyelenggarakan administrasi kartu-kartu yang dibutuhkan oleh bank.

Aktivitas $\quad$ : Rutinitas kerja yang kita lakukan dengan adanya tujuan yang ingin dicapai

Operasional $\quad$ : Bersifat operasi atau berhubungan dengan operasi/kegiatan perusahaan yang bersifat berkesinambungan.

Bank : Suatu badan lembaga keuangan yang berfungsi sebagai financial intermediary atau perantara keuangan dari dua belah pihak, yakni : pihak yang kelebihan dana dengan pihak yang kekurangan dana.

\section{ANALISA DAN PEMBAHASAN}

Peranan CS dalam meningkatkan pelayanan terhadap nasabah pada PT.Bank Syari'ah Mandiri merupakan kunci sukses dan dasar untuk membangun keberhasilan bank tersebut. Oleh karena itu, segala kegiatan harus berjalan dengan baik dan bermutu demi terciptanya kepuasan nasabah. Karena nasabah yang merasa mendapat kepuasan akan kemabali lagi mendatangi bank tersebut dan membeli produk lain yang ditawarkan oleh bank serta akan berbagi cerita dengan rekan lainnya.

\section{Persiapan Awal Kerja}

Adapun aktivitas yang dilakukan CS pada PT.Bank Syari'ah Mandiri cabang Padang pada awal hari (persiapan kerja) adalah sebagai berikut:

1) Memastikan area kerja CS telah "secure" dan terbebas dari gangguan maupun adanya pihak-pihak yang tidak berkepentingan

2) Memastikan seluruh peralatan kerja CS lengkap, dapat digunakan/berfungsi dengan baik, terutama meja yang bersih \& rapih, kursi menghadap nasabah, pesawat telepon, jam, kalender, alat tulis, brosur umum, kertas/notes, komputer/printer, tempat sampah yang telah bersih.

3) Memastikan komputer telah dinyalakan dan berfungsi dengan baik serta hanya password CS yang sedang bertugas yang dapat diaktifkan.

4) Memastikan seluruh sarana pemasaran (Marketing kits \& promotion tools), gimmick, informasi produk/layanan, berbagai leaflet, formulir (beserta alat bantunya antara lain ballpen) yang diperlukan nasabah telah mencukupi, berfungsi dan tersedia pada tempatnya. 
5) Mengecek apabila ada pengumuman hari itu yang harus diketahui CS terkait dengan bidang tugasnya, termasuk yang harus diinformasikan ke nasabah (misalnya perubahan pejabat cabang, alamat, nomor telepon, nomor rekening atau perubahan ketentuan BI maupun intern BSM)

6) Memastikan kelengkapan formulir-formulir untuk kebutuhan layanan kepada nasabah (slip penyetoran/penarikan, aplikasi transfer/NPB, aplikasi Payment Point telkom/pajak/IM3/PLN, aplikasi pembukaan rekening Giro/Tabungan/Deposito), stempel perusahaan, materai, kartu spesimen tanda tangan, stok kartu ATM maupun formulir isian tambahan terkait KYC telah terpenuhi.

7) Memperhatikan penampilan diri antara lain, seragam bersih \& rapih, make-up, senyum, kerapihan counter, pencahayaan, akses datang/pergi nasabah ke/dari area CS serta kemudahan menjangkau peralatan \& sarana kerja lainnya.

8) Mengecek kondisi dan suasana Banking Hall cabang terkait dengan kebersihan, keindahan, kelancaran, kenyamanan, keamanan dan kepercayaan nasabah kepada BSM telah memadai dan dapat mendukung pelayanan yang baik (misalnya flow of customer, pemandangan, suara, bau, informasi dan berbagai sarana penunjangnya).

\section{Saat Melayani Nasabah (Jam Kerja)}

1) Memulai memberikan "|salam" dan "senyum" kepada nasabah yang datang maupun komunikasi lewat telepon.

2) Menerapkan standar kualitas pelayanan antara lain standar penyebutan nama, menginformasikan agar nasabah menunggu sebentar karena sedang diproses.

3) Memperhatiakn antrian nasabah yang akan berhubungan dengan layanan CS, memanggil/melayani nasabah yang terdepan/sesuai nomor urut dengan cepat, jelas, ramah, teliti, tegas, tepat, dan sopan, serta menanyakan/respon terhadap nasabah yang lama menunggu.

4) Segera membantu dan membimbing nasabah yang bertanya atau mengalami kesulitan mengisi formulir/memahami produk \& layanan/informasi tertulis.

5) Memisahkan/mengelompokan dokumen penting, bukti transaksi ataupun catatan tertentu (misalnya adanya nasabah yang mencurigakan)

6) Segera menunjukkan bahwa CS melakukan langkah-langkah penggunaan/penerusan sarana pelayanan antara lain akses ke komputer, pengecekan data nasabah, telepon, informasi saldo, perlunya kebagian lain, proses keatasan, brosur \& Marketing Tools yang diperlukan

7) Segera mencatat hal-hal baru guna mencegah permasalahan dikemudian hari (misalnya keinginan nasabah atas produk tertentu yang belum ada, perubahan data nasabah, saran-saran, kekurangan yang belum diperoleh nasabah, jadwal penting terkait dengan 
pelayanan/informasi bagi nasabah, janji untuk menghubungi nasabah lagi, complaint dll) dan menindaklanjuti usul keatasan jika ada yang harus segera dilaporkan kekantor pusat.

8) Memperhatikan dengan seksama setiap pertanyaan/pernyataan/laporan nasabah dan segera mencatat, mencarikan/memberikan jawaban/solusi/penerusannya tanpa mengurangi kualitas pelayanan yang baik antara lain kecepatan, kejelasan, keakuratan, validitas, kewenangan, kebenaran, keramahan, kesopanan, ketegasan, kooperatif, dialogis dan penyelesaian yang informatif \& memuaskan (misalnya bertanya tentang produk baru, keluhan BSM prakteknya kurang syari'ah, kehilangan buku Tabungan/bilyet Giro dsb).

\section{Pembukaan dan Penutupan Rekening Giro}

Menurut UU RI No.10 tahun 1998-pasal 1 (6) yang dimaksud dengan Giro adalah simpanan yang penarikannya dapat dilakukan setiap saat dengan menggunakan cek, bilyet Giro, sarana perintah pembayaran lainnya atau dengan cara pemindahbukuan.

1) Proses Pembukaan Rekening Giro

a. Menjelaskan syarat-syarat umum pembukaan rekening seperti setoran minimal pertama, saldo minimal, nisbah bagi hasil/bonus serta menawarkan fasilitas lainnya seperti ATM, autodebit, SMS Banking, Payment Point dll

b. Meminta nasabah mengisi dan menandatangani formulir pembukaan rekening Giro, syarat-syarat umum pemegang rekening Giro, Kartu Contoh Tanda Tangan Giro, permintaan buku cek/bilyet Giro dan dokumen lainnya yang diperlukan.

c. Meminta identitas nasabah yang sah dan masih berlaku sesuai statusnya, untuk perorangan :KTP, SIM, Passport dan badan hukum : Anggaran dasar dan perubahannya

d. Mencocokan kesesuaian tanda tangan nasabah pada kartu identitas dengan yang tertera pada formulir pembukaan rekening Giro. Khusus untuk badan hukum dicek kebenaran nama yang berwenang dalam anggaran dasar dengan identitasnya

e. Membubuhkan stempel verifikasi dan paraf disamping tanda tangan nasabah yang tertera pada formulir pembukaan rekening Giro

f. Membubuhkan stempel "SESUAI DENGAN ASLINYA" dan paraf pada fotocopy kartu identitas

g. Mengecek apakah nasabah termasuk dalam daftar hitam Bank Indonesia

h. Mencatatat pada buku Register Pembukaan Rekening Giro dan mencantumkan Nomor Registrasi Nasabah dan Nomor Rekening pada formulir pembukaan rekening Giro

i. Memberikan seluruh berkas pembukaan rekening Giro kepada Manajer Pemasaran untuk diperiksa kebenarannya dan mendapatkan persetujuannya 
j. Melakukan input data nasabah dan pembukaan rekening Giro pada sistem AS.400 dan mintakan persetujuan/otorisasi dari Manajer Pemasaran/Manajer Operasional/Kepala Cabang/Kepala Kantor Cabang Pembantu/Kepala Kantor Kas

k. Melengkapi data pada kolom "Diisi oleh Bank" (No.Rekening, Nisbah Bagi Hasil, Setoran Pertama) dan membubuhkan tanda tangan pada formulir pembukaan rekening Giro

1. Meminta nasabah mengisi slip setoran dan mencantumkan nomor rekening Giro nasabah

m. Meminta kepada nasabah melakukan penyetoran awal melalui Teller

n. Melakukan input data KCTT (Kartu Contoh Tanda Tangan) nasabah Giro dan scanning KCTT dengan menggunakan aplikasi PCISign, kemudian melakukan konfirmasi kepada Manajer Pemasaran/Manajer Operasi/Kepala Cabang/Kepala Cabang Pembantu/Kepala Kantor Kas untuk diverifikasi.

o. Menyerahkan KCTT Giro kepada Teller dan Manajer Pemasaran/Manajer Operasi/Kepala Cabang/Kepala Cabang Pembantu/Kepala Kantor Kas untuk disimpan pada lemari specimen tanda tangan (cardex)

p. Menyerahkan formulir permintaan buku cek/bilyet Giro kepada bagian umum untuk disiapkan (cetak nomor rekening dan encode) dan dilakukan pembebanan biaya pembelian buku cek/bilyet Giro ke rekening Giro nasabah secara tunai

q. Menyerahkan buku cek/bilyet Giro kepada nasabah dengan menggunakan buku administrasi tanda terima dan melakukan input resi tanda terima buku cek/bilyet Giro yang telah ditandatangani oleh nasabah ke sistem AS.400 untuk mendaftarkan nomor register cek/bilyet Giro

r. Menyimpan (file) berkas pembukaan rekening Giro dengan tertib pada tempat yang aman.

2) Proses Penutupan Rekening Giro

a. Meminta nasabah untuk mengisi dan menandatangani formulir penutupan rekening Giro, mnyerahkan Buku Tabungan serta menjelaskan biaya penutupan rekening

b. Melihat saldo rekening pada AS.400 dan catat pada saldo tersebut pada formulir penutupan rekening Giro dan dikurangi biaya penutupan rekening

c. Meminta kepada nasabah Giro untuk menyerahkan sisa buku Cek/Bilyet Giro yang masih berada ditangan nasabah pada sistem AS. 400

d. Melakukan pengecekan data nasabah menurut formulir penutupan rekening Giro dengan berkas rekening Giro yang ada

e. Melakukan input data program penutupan rekening Giro dan mintakan otorisasi kepada Manajer Pemasaran/Manajer 
Operasional/Kepala Cabang/Kepala Cabang Pembantu/Kepala Kantor Kas

f. Meminta nasabah untuk mengisi buku cek untuk rekening Giro sebagai sarana pencairan saldo rekening Tabungan

g. Meminta nasabah untuk melakukan pencairan melalui Teller

h. Membubuhi stempel "ditutup" pada semua berkas pembukaan rekening Giro dan menyimpan pada file khusus rekening yang telah ditutup secara tertib.

i. Menghapus data dan contoh tanda tangan nasabah Giro pada aplikasi PCISign, kemudian melakukan konfirmasi kepada Manajer Pemasaran/Manajer Operasional/Kepala Cabang/Kepala Cabang Pembantu/Kepala Kantor Kas untuk diverifikasi.

\section{Pembukaan dan Penutupan Rekening Tabungan}

Rekening Tabungan adalah simpanan masyarakat yang penarikannya hanya dapat dilakukan menurut syarat tertentu yang disepakati, tetapi tidak dapat ditarik dengan cek, bilyet Giro atau alat yang dapat dipersamakan dengan itu. Penarikan nya dapat dilakukan dengan manggunakan slip penarikan.

1) Proses Pembukaan Rekening Tabungan

a. Menjelaskan syarat-syarat umum pembukaan rekening Tabungan seperti setoran minimal pertama, saldo minimal, nisbah bagi hasil/bonus serta menawarkan fasilitas lainnya seperti ATM, autodebit, SMS Banking, Payment Point dll

b. Meminta nasabah mengisi dan menandatangani formulir pembukaan rekening Tabungan

c. Meminta identitas nasabah yang sah dan masih berlaku sesuai statusnya, untuk perorangan :KTP, SIM, Passport dan badan hukum : Anggaran dasar dan perubahannya

d. Mencocokan kesesuaian tanda tangan nasabah pada kartu identitas dengan yang tertera pada formulir pembukaan rekening Tabungan. Khusus untuk badan hukum dicek kebenaran nama yang berwenang dalam anggaran dasar dengan identitasnya

e. Membubuhkan stempel verifikasi dan paraf disamping tanda tangan nasabah yang tertera pada formulir pembukaan rekening Tabungan

f. Membubuhkan stempel "SESUAI DENGAN ASLINYA" dan paraf pada fotocopy kartu identitas

g. Mengecek apakah nasabah termasuk dalam daftar hitam Bank Indonesia

h. Mencatat pada buku Register Pembukaan Rekening Tabungan dan mencantumkan Nomor Registrasi Nasabah dan Nomor Rekening pada formulir pembukaan rekening Tabungan

i. Memberikan seluruh berkas pembukaan rekening Tabungan kepada manajer pemasaran untuk diperiksa kebenarannya dan mendapatkan persetujuannya

j. Melakukan input data nasabah dan pembukaan rekening Tabungan pada sistem AS.400 dan mintakan persetujuan/otorisasi dari 
Manajer Pemasaran/Manajer Operasional/Kepala Cabang/Kepala Kantor Cabang Pembantu/Kepala Kantor Kas

k. Melengkapi data pada kolom "Diisi oleh Bank" (No.Rekening, Nisbah Bagi Hasil, Setoran Pertama) dan membubuhkan tanda tangan pada formulir pembukaan rekening Tabungan

1. Meminta nasabah mengisi slip setoran dan mencantumkan nomor rekening Tabungan nasabah

m. Meminta kepada nasabah melakukan penyetoran awal melalui Teller

n. Untuk pembukaan rekening Tabungan, nasabah diminta untuk menandatangani kotak tanda tangan pada Buku Tabungan dengan kertas specimen (overlay paper) dan menutup dengan sticker ultraviolet (UV) Signature Tape, lalu membubuhi stempel BSM

o. Meminta Manajer Pemasaran untuk membubuhkan tanda tangan dan nama jelas pada Buku Tabungan, lalu menyerahkan Buku Tabungan kepada nasabah

p. Menyimpan (file) berkas pembukaan rekening Tabungan dengan tertib pada tempat yang aman (lemari terkunci)

2) Proses Penutupan Rekening Tabungan

a. Meminta nasabah untuk mengisi dan menandatangani formulir penutupan rekening Tabungan, mnyerahkan Buku Tabungan serta menjelaskan biaya penutupan rekening

b. Melihat saldo rekening pada AS.400 dan catat pada saldo tersebut pada formulir penutupan rekening Tabungan dan dikurangi biaya penutupan rekening

c. Melakukan pengecekan data nasabah menurut formulir penutupan rekening Tabungan dengan buku Tabungan yang bersangkutan

d. Melakukan input data program penutupan rekening Tabungan dan mintakan otorisasi kepada Manajer Pemasaran/Manajer Operasional/Kepala Cabang/Kepala Cabang Pembantu/Kepala Kantor Kas

e. Meminta nasabah untuk mengisi slip penarikan Tabungan sebagai sarana pencairan saldo rekening Tabungan

f. Meminta nasabah untuk melakukan pencairan melalui Teller

g. Membubuhi stempel "ditutup" pada semua berkas pembukaan rekening Tabungan dan menyimpan pada file khusus rekening yang telah ditutup secara tertib.

\section{Pelayanan Pembukaan dan Pencairan Deposito}

Simpanan Deposito adalah simpanan jenis ketiga yang diberikan oleh bank. Berbeda dengan dua jenis simpanan sebelumnya dimana simpanan Deposito mengandung unsur jangka waktu (jatuh tempo) lebih panjang dan tidak dapat ditarik setiap saat atau setiap hari. Dengan kata lain Deposito itu merupakan simpanan yang penarikannya hanya dapat dilakukan pada waktu tertentu menurut perjanjian antar penabung dengan bank yang bersangkutan. 
1) Proses pembukaan Deposito

a. Menjelaskan ketentuan umum tentang pembukaan Deposito seperti nisbah, bagi hasil, biaya administrasi, cara pembayaran bagi hasil, perpanjangan otomatis, pencairan sebelum jantuh tempo dan menanyakan apakah nasabah baru atau sudah pernah memiliki rekening di BSM untuk kepentingan CIF (Customer Informatian file)

b. Meminta nasabah mengisi dan menandatangani formulir pembukaan Deposito

c. Meminta identitas nasabah yang sah dan masih berlaku sesuai statusnya, untuk perorangan : KTP, SIM, Passport, Kartu Pelajar dll. Dan badan hukum: anggaran dasar dan perubahannya

d. Mencocokkan kesesuaian tanda tangan nasabah pada kartu identitas dengan yang tertera pada formulir pembukaan Deposito. Khusus untuk badan hukum dicek kebenaran nama yang berwenang dalam anggaran dasar dengan identitasnya

e. Membubuhkan stempel verifikasi dan paraf disamping tanda tangan nasabah yang tertera pada formulir pembukaan Deposito

f. Membubuhkan stempel "SESUAI DENGAN ASLINYA" dan paraf pada fotocopy kartu identitas

g. Melakukan input data nasabah terlebih dahulu pada AS.400 dan minta otorisasi dari Manajer Operasi/Kepala Cabang/Kepala Kantor Cabang Pembantu

h. Meminta nasabah untuk menyetor dengan menyerahkan formulir pembukaan Deposito kepada Teller

i. Menerima bilyet Deposito lembar 1 dan 2 yang telah ditandatangani oleh Manajer Operasi/Kepala Cabang/Kepala Kantor Cabang Pembantu

j. Menyerahkan asli Bilyet Deposito lembar 1 kepada nasabah dan nasabah diminta untuk menandatangani copy Bilyet Deposito lembar 2 sebagai tanda terima

k. Menyerahkan copy bilyet Deposito lembar 2 kepada petugas Deposito untuk diadministrasikan.

2) Proses Pencairan Deposito

a. Nasabah menyerahkan bilyet Depositonya, kemudian petugas CS mencocokkan tandatangan

b. CS mengambil formulir pencairan Deposito dan menanyakan, apakah nasabah ingin dananya dipindah bukukan atau dicairkan secara tunai, jika pindah buku maka: ambil KCTT yang telah diarsip, kemudian cocokkan tandatangan, setelah cocok baru pindahkan dana tersebut ke rekening nasabah. Jika nasabah ingin menarik secara tunai maka: ambil KCTT yang telah diarsip, cocokkan tandatangan, setelah itu masukkan dana nasabah ke rekening perantara, penarikan bisa dilakukan melalui Teller lewat rekening perantara 
Pelayanan Transaksi Jasa-jasa Transfer, Pemindahbukuan, Inkaso/Intercity Clearing

Seorang petugas CS harus memberi penjelasan kepada nasabah yang membutuhkan informasi mengenai:

1) Menjelaskan ketentuan tarif transfer/inkaso yang berlaku dan hasil inkaso kepada nasabah

2) Meminta nasabah mengisi dan menandatangani formulir permohonan transfer/pemindahbukuan/inkaso

3) Meminta kepada nasabah menyetor tunai/atas beban rekening dan menyerahkan permohonan transfer/pemindahbukuan/inkaso dengan warkat inkasonya termasuk pembayaran biayanya ke Teller.

Pelayanan Permohonan ATM dan SMS Banking

1) Menjelaskan syarat dan ketentuan mengenai ATM dan SMS Banking telah memiliki rekening Tabungan terlebih dahulu, jenis ATM, lamanya proses persetujuan, tarif biaya setiap transaksi dan lain-lain kepada nasabah

2) Meminta nasabah mengisi dan menandatangani formulir permohonan ATM dan SMS Banking

3) Meminta identitas nasabah yang sah dan masih berlaku sesuai statusnya, untuk perorangan : KTP, SIM, Passport

4) Mencocokkan kesesuaian tanda tangan nasabah pada kartu identitas dengan yang tertera pada formulir permohonan ATM dan SMS Banking

5) Membubuhkan stempel "SESUAI DENGAN ASLINYA" dan paraf pada fotocopy kartu identitas

6) Mencatat pada buku administrasi kontrol pendaftaran permohonan ATM dan SMS Banking dan diparaf sebagai sarana monitoring penyelesaian oleh kantor pusat

7) Menyerahkan formulir permohonan ATM dan SMS Banking beserta asli dan copy kartu identitas nasabah kepada Manajer Operasi/Kepala Cabang/Kepala Cabang Pembantu untuk minta persetujuannya

8) Menerima formulir permohonan ATM dan SMS Banking yang telah ditandatangani oleh Manajer Operasi/Kepala Cabang/Kepala Cabang Pembantu beserta asli dan copy identitas nasabah

9) Mendistribusikan formulir permohonan ATM dan SMS Banking yaitu lembar 1 untuk nasabah, lembar 2 untuk dikirim ke kantor pusat (ATM Centre) dan lembar 3 untuk arsip cabang

10) Setelah menerima kartu ATM dan PIN Mailer (untuk ATM) dan bukti pndaftaran nasabah dan PIN Mailer (untuk SMS Banking) dari kantor pusat (ATM Centre), menghubungi nasabah untuk mengambil

11) Menyerahkan kartu ATM dan PIN Mailer (untuk ATM) dan PIN Mailer (untuk SMS Banking) kepada nasabah dengan menggunakan sarana tanda terima

12) Untuk SMS Banking, pada formulir permohonan SMS Banking dicatat "tanggal aktivasi" 


\section{Pelayanan Transaksi Autodebit}

1) Meminta nasabah untuk mengisi dan menandatangani formulir standing Instructanding Instruction dengan data pada bukti identitas diri atau buku Tabungan/kartu ATM, melalui data nasabah pada AS. 400

2) Melakukan input data formulir standing Instruction pada AS.400 untuk Autodebit selain pembayaran payment dan meminta otorisasi kepada Manajer Pemasaran/Manajer Operasi/Kepala Cabang/Kepala Kantor Cabang Pembantu/Kepala Kantor Kas

3) Membubuhkan paraf pada formulir Standing Intruction dan menyerahkannya kepada Manajer Pemasaran/Manajer Operasi/Kepala Cabang/Kepala Kantor Cabang Pembantu/Kepala Kantor Kas untuk disetujui/ditandatangani

4) Apabila permintaan Autodebit yang berhubungan dengan pembayaran payment point (Telkom, IM3, Satelindo, Retelindo dll) input data nasabah dilaksanakan oleh KP.DOA, maka formulir Standing Instruction yang telah ditandatangani oleh Manajer Pemasaran/Manajer Operasi/Kepala Cabang/Kepala Kantor Cabang Pembantu/Kepala Kantor Kas dikirm via faximile ke KP.DOA 02139832990 dan dikonfrimasi ulang melalui telepon atas pengiriman data tersebut, begitu juga apabila terjadi pancabutan Autodebit, maka surat pernyataan pencabutan dari nasabah dikirim ke KP.DOA untuk diproses pencabutannya.

5) Menyerahkan fotocopy 2 lembar Standing Intruction kepada nasabah sebagai bukti

6) Menyimpan (file) formulir Standing Intruction dengan tertib pada tempat yang aman.

\section{Permintaan Buku Cek/Bilyet Giro}

1) Menerima aplikasi permintaan buku cek/bilyet Giro nasabah

2) Menyerahkan aplikasi permintaan buku cek/bilyet Giro kepada petugas bagian umum untuk disiapkan setelah mendapatkan persetujuan Manajer Operasi/Kepala Cabang/Kepala Cabang Pembantu

3) Menyerahkan buku cek/bilyet Giro kepada nasabah dengan menggunakan buku administrasi tanda terima dan melakukan input resi tanda terima buku cek/bilyet Giro yang telah ditandatangani oleh nasabah ke sistem AS.400 untuk mendaftarkan nomor register cek/bilyet Giro.

Permintaan Pencetakan Salinan Rekening Koran/Advis/Tiket Transaksi

1) Menerima permintaan pencetakan salinan rekening koran/advis/tiket transaksi dari nasabah

2) Meneruskan permintaan tersebut kepada Manajer Operasi/Kepala Cabang/Kepala Cabang Pembantu untuk mendapatkan persetujuannya

3) Menyampaikan hasil pencetakan salinan rekening koran/advis/tiket kepada nasabah dengan menggunakan sarana tanda terima. 
Pelayanan Perintah Pemblokiran Rekening

1) Menerima surat permintaan pemblokiran dari nasabah

2) Meneruskan surat permintaan pemblokiran kepada Manajer Operasi/Manajer Pemasaran/Kepala Cabang/Kepala Cabang Pembantu/Kepala Kantor Kas untuk mendapatkan persetujuan

3) Menginformasikan kepada nasabah bahwa permintaannya telah dilaksanakan sesuai

\section{Khusus Input Customer Information File}

1) Pastikan seluruh data yang harus diisi oleh nasabah telah dilengkapi dan benar

2) Apakah data yang diperoleh dari bagian lain telah lengkap dan telah mendapatkan pengesahan dari pejabat yang berwenang

3) Apakah data yang telah diinput ke komputer tidak ada yang tertinggal

4) Apakah hasil input data telah dicek ulang yaitu kelengkapan dan kebenerannya serta penyimpanan ke data-based telah selesai

5) Apakah prosedur penginputan data telah sesuai/mengikuti ketentuan yang berlaku

6) Apakah atas kekurangan data telah dicatat dan segera dimintakan kelengkapannya kepada nasabah atau bagian lain yang terkait

7) Apakah tambahan data atas kekurangan sebelumnya telah dicek dan diinput dengan benar

8) Apakah atas perubahan/koreksi data yang ada telah dilakukan penginputan dengan benar

9) Apakah penginputan data baru/koreksi berdasarkan perintah yang telah mendapatkan persetujuan/pengesahan dengan adanya tandatangan atau paraf dari pejabat yang berwenang

Aktivitas Saat Jam Istirahat Jika CS Tidak Berada ditempat

1) Menutup tempat-tempat/penyimpanan dokumen/data rahasia dari kemungkinan adanya penyalahgunaan

2) Memposisikan komputer pada kondisi "menu utama" dan log-off

3) Mengatur waktu antara pelayanan kepada nasabah, istirahat dan pengalihan sementara (bergiliran) kepada pegawai lain atau atasan agar dapat berjalan dengan baik

4) Memastikan nasabah penting (priority) tertangani dan tidak membiarkannya dalam kondisi tidak memperoleh pelayanan ataupun ketidak jelasan

5) Memastikan nasabah-nasabah yang harus menunggu tidak terkesan "ditelantarkan:".

\section{Menangani Complaint Nasabah}

1) Meyakinkan diri bahwa tidak seluruh nasabah "merasa" tidak dilayanai dengan baik/benar, namun menyadari bahwa setiap nasabah perlu mendapat perlakuan yang sama, meskipun jenis pelayanan yang berbeda

2) Meyakini bahwa setiap masalah (complaint) yang disampaikan nasabah ke CS adalah cerminan anggapan masyarakat terhadap BSM

3) Menyadari bahwa setiap masalah pasti ada sebab dan solusinya 
4) Menyadari bahwa tidak seluruh complaint harus selalu diselesaikan tuntas, namun harus tetap ditanggapi oleh CS

5) Melaksanakan bahwa kesan awal bagi nasabah terhadap tanggapan CS atas complaint yang disampaikan adalah hal yang paling penting diperhatikan dan menentukan efektifitas pelayanan BSM misalnya ucapan terimakasih atau kami dapat memahami dan sebagainya

6) Menerapkan bahwa mendengar dengan aktif, efektif dan baik adalah akan mambantu menemukan sumber permasalahan dan akan mengarah kepada solusi yang dibutuhkan serta dapat diberikan oleh BSM

7) Setiap menerima complaint dari nasabah yang tidak dapat diatasi sendiri oleh CS, apakah segera dilaporkan permasalahnnya kepada Manajer Operasi/Manajer Pemasaran/ Kepala Cabang/Kepala Cabang Pembantu/Kepala Kantor Kas untuk mendapatkan solusi penyelesaiainnya

8) Memastikan bahwa menangani complaint nasabah menjadi bagian dari upaya Marketing dan perlu menunjukkan sikap empaty dan sympati

\section{Aktivitas CS di Sore Hari sebelum Jam Kerja Berakhir}

1) Apakah pelayanan atas pending pada ahri itu telah ditindak lanjuti

2) Apakah pihak-pihak nasabah yang harus di hubungi hari itu juga telah diselesaikan

3) Apakah tugas penting/pokok/prinsipil yang harus selesai dalam hari itu telah seluruhnya dicek kebenarannya misalnya kewenangan, input data nasabah, penandatanganan, kelengkapan dokumen, kesesuain copy dengan asli, pemenuhan kewajiban KYC.

\section{Aktivitas CS Pada Saat Penutupan}

1) Apakah seluruh dokumen, formulir, aplikasi, rekap, laporan telah diselesaikan dengan baik dan sesuai

2) Apakah hal-hal penting telah dicatat dan ditetapkan jadwal tindak lanjutnya serta disimpan

3) Apakah seluruh dokumen penting telah disimpan pada tempatnya dengan aman dan tertib

4) Apakah tugas-tugas yang terkait dan harus diteruskan kepada bidang lain telah seluruhnya disampaikan dengan jelas dan benar

5) Apakah hal-hal/informasi yang harus diketahui atasan telah disampaikan dan diterima atasan

6) Apakah arahan-arahan atasan telah dicermati dan langkah-langkah yang harus diambil telah dipenuhi, sedangkan jika ada yang terpaksa tertunda telah ditetapkan dead-line nya

7) Apakah terminal CS telah dimatikan (sign off) dan seluruh sarana serta prasarana termasuk area kerja CS kerja telah "aman" dan dipastikan tidak ada yang hilang 


\section{KESIMPULAN}

Berdasarkan uraian dan pembahasan yang telah dikemukakan pada bab sebelumnya, maka dapat diambil kesimpulan sebagai berikut:

1) Customer service adalah setiap kegiatan yang diperuntukkan atau ditujukan untuk memberi kepuasan nasabah, melalui pelayanan yang bermutu yang dapat memenuhi keinginan dan kebutuhan nasabah.

2) Mekanisme kerja CS pada saat pagi hari yaitu menyiapkan counter CS bersih, rapih dan senyaman mungkin. Kemudian pada saat jam kerja CS benar-benar harus fokus terhadap pelayanan kepada nasabah, mulai dari pembukaan dan penutupan rekening Giro, pembukaan dan penutupan rekening Tabungan, pembukaan dan pencairan Deposito, serta melayani semua kebutuhan dan keluhan nasabah. Pada jam istirahat petugas CS harus bergantian, karena counter CS tidak boleh kosong. Kemudian waktu sore hari dan tutup harian, CS harus telah menyelesaikan semua tugas pada hari itu, dan membuat dead-line untuk tugas yang dipending dan akan dikerjakan esok harinya.

3) Produk dan jasa yang ditawarkan oleh BSM adalah:

a. Produk Pendanaan
a) Giro
b) Tabungan
c) Deposito

b. Produk Pembiayaan

c. Produk Jasa

4) Rekening Giro adalah Menurut UU RI No.10 tahun 1998-pasal 1 (6) yang dimaksud dengan Giro adalah simpanan yang penarikannya dapat dilakukan setiap saat dengan menggunakan cek, bilyet Giro, sarana perintah pembayaran lainnya atau dengan cara pemindahbukuan.

5) Rekening Tabungan adalah simpanan masyarakat yang penarikannya hanya dapat dilakukan menurut syarat tertentu yang disepakati, tetapi tidak dapat ditarik dengan cek, bilyet Giro atau alat yang dapat dipersamakan dengan itu. Penarikannya dapat dilakukan dengan manggunakan slip penarikan.

6) Simpanan Deposito adalah simpanan jenis ketiga yang diberikan oleh bank. Berbeda dengan dua jenis simpanan sebelumnya dimana simpanan Deposito mengandung unsur jangka waktu (jatuh tempo) lebih panjang dan tidak dapat ditarik setiap saat atau setiap hari. Dengan kata lain Deposito itu merupakan simpanan yang penarikannya hanya dapat dilakukan pada waktu tertentu menurut perjanjian antar penabung dengan bank yang bersangkutan. 


\section{DAFTAR PUSTAKA}

As. Mahmoeddin, Etiket Pelayanan Bank "Petunujuk Praktis MenjaringNasabah” (Jakarta: PT.Tko Gunung Agung, 1995)

Departemen Pendidikan dan Kebudayaan, Kamus Besar Bahasa Indonesia, (Jakarta: Balai Pustaka, 1990), hal.849

E Juana Wijaya, Pelayanan Prima dan Bisnis Manjemen, (Jakarta: Erlangga, 1985)

Febryani Anita, Kajian Ekonomi dan Keuangan, (Jakarta: 4 Desember 2003)

Fernandes, Y. D., \& Marlius, D. (2018). Peranan Customer Service Dalam Meningkatkan Pelayanan Kepada Nasabah Pada PT. Bank Pembangunan Daerah Sumatera Barat Cabang Utama Padang. https://doi.org/10.31227/osf.io/wrh3p

Kasmir, SE,MM, Pemasaran Bank, (Jakarta: Prenada Media, 2004), hal.202

Mirawati \& Fernos, J. (2019). Peranan Customer Service Dalam Meningkatkan Pelayanan Terhadap Nasabah Pada Bank Nagari Cabang Siteba Padang. https://doi.org/10.31227/osf.io/cq458

Muchdarsyah Sinungan, Manajemen dan Bank, (Jakarta: PT.Bumi Aksara, 1993)

Prasetyo, Z., \& Afriyeni, A. (2019). Penerapan Manajemen Resiko Operasional Pada PT. Bank Pembangunan Daerah Sumatera Barat Cabang Painan Kabupaten Pesisir Selatan. https://doi.org/10.31219/osf.io/83ea4

SK.Menteri Keuangan RI (Nomor 792,1990)

Susanti, F. W Ekazaputri. (2018). Service Performance Dan Kepuasan Sebagai Moderating Variabel Terhadap Loyalitas Nasabah Pada PT BPR Labuh Gunung Payakumbuh Jurnal Benefita: Ekonomi Pembangunan Manajemen Bisnis Dan Akuntansi. Volume 3. No. 3. Hal. 433444.http://doi.org/10.22216/jbe.v3i3.3472

UU.Perbankan (No.10, 1998) 